Counsellia: Jurnal Bimbingan dan Konseling, 9 (1), $2019 \not 79$ - 88

Copyright (C2019 Universitas PGRI Madiun

ISSN: 2088-3072 (Print) / 2477-5886 (Online)

Available online at: http://e-journal.unipma.ac.id/index.php/JBK

DOI: $10.25273 /$ counsellia.v9i1.4301

\title{
Analisis perilaku cyberbullying ditinjau dari big five personality dan kemampuan literasi sosial media
}

\author{
Noviyanti Kartika Dewi ${ }^{1}$, Dian Ratnaningtyas Affifah ${ }^{2}$ \\ ${ }^{1}$ Fakultas Keguruan dan Ilmu Pendidikan, Universitas PGRI Madiun. Madiun \\ noviyantibk@unipma.ac.id \\ ${ }^{2}$ Fakultas Keguruan dan Ilmu Pendidikan, Universitas PGRI Madiun. Madiun \\ dian.afifah@unipma.ac.id
}

\begin{abstract}
Abstrak
Bullying sudah mulai berevolusi menjadi Cyberbullying. Cyberbullying merupakan segala bentuk kekerasan (mengejek, menghina, mengintimidasi, atau mempermalukan) dengan memanfaatkan teknologi digital ataupun media sosial yang dilakukan oleh remaja kepada teman sebayanya. Kepribadian dilihat sebagai salah satu faktor yang berpengaruh terhadap terbentuknya perilaku cyberbullying. Penelitian ini bertujuan untuk mengkaji perilaku cyberbullying dikalangan mahasiswa ditinjau dari trait big five personality dan kemampuan literasi media sosial. Populasi penelitian ini adalah mahasiswa Universitas PGRI Madiun dengan jumlah sebanyak 350 mahasiswa. Metode pengumpulan data menggunakan skala psikologis yang terdiri dari skala cyberbullying, big five personality dan literasi sosial media. Hasil penelitian menunjukkan bahwa perilaku cyberbullying berada pada kategori rendah. Big five personality mahasiswa UNIPMA berada pada kategori Openness dan Extraversion sedangkan kemampuan literasi media mahasiswa UNIPMA berada pada kategori tinggi. Adapun korelasi antara cyberbullying dan big five peronality adalah negatif artinya semakin tinggi big five personality maka perilaku cyberbullying rendah. Begitupula dengan korelasi perilaku cyberbullying dengan literasi media juga berkorelasi negatif yang artinya semakin tinggi literasi media maka semakin rendah perilaku cyberbullyingnya.
\end{abstract}

Keywords : Cyberbullying, Big Five Personality, Literasi Sosial Media.

\begin{abstract}
Bullying has begun to evolve into Cyberbullying. Cyberbullying is all forms of violence (mocking, insulting, intimidating, or humiliating) by utilizing digital technology or social media by teenagers to their peers. Personality is seen as one of the factors that influence the formation of cyberbullying behavior. This study aims to examine cyberbullying behavior among students in terms of big five personality traits and social media literacy abilities. The population of this study was 350 students from the University of PGRI Madiun. The method of data collection uses a psychological scale consisting of the scale of cyberbullying, big five personality and social media literacy. The results showed that cyberbullying behavior was in the low category. The big five personality of UNIPMA students is in the Openness and Extraversion category while the media literacy abilities of UNIPMA students are in the high category. The correlation between cyberbullying and big five peronality is negative, which means the higher the big five personality, the lower cyberbullying behavior. Likewise, the behavior of cyberbullying correlations with media literacy is also negatively correlated, which means that the higher the media literacy, the lower the cyberbullying behavior.
\end{abstract}

Keywords : Cyberbullying, Big Five Personality, Literasi Social Media. 



\section{PENDAHULUAN}

Perkembangan

dunia

teknologi khususnya yang terkait internet saat ini sedemikian pesatnya. Siapa diantara kita yang tidak mengenal internet? Munculnya internet merupakan salah satu penemuan yang berharga di era milineal, karena banyak kemudahan yang bisa didapatkan dengan menggunakan internet. Jaringan internet hampir menyentuh semua aspek kehidupan manusia, hampir tidak ada individu yang tidak mengenal dan menggunakan internet. Internet banyak digunakan di berbagai bidang kehidupan individu seperti pada pelayanan publik, pendidikan dan pembelajaran, komunikasi dan juga dunia hiburan. Dengan demikian jelaslah bahwa internet ada dan berpengaruh pada semua sektor kehidupan individu.

Pesatnya perkembangan teknologi seperti internet ternyata membawa dampak terhadap berubahnya pola perilaku masyarakat baik di perkotaan ataupun pedesaan dimana telah terjadi evolusi penggunaan internet (Dewi \& Trikusumaadi, 2017). Pada awalnya internet hanya berfungsi sebagai alat komunikasi namun saat ini internet telah beralih pada penggunaan yang lebih spesifik. Selain itu temuan studi lain menunjukkan bahwa masyarakat pengguna internet adalah yang berpendidikan tinggi (well educated) dan mampu secara fnansial (wellfinanced).

Berdasarkan data kementrian komunikasi dan informatika (kemenkominfo) tahun 2017 menunjukkan bahwa pengguna internet di Indonesia sebesar 63 juta orang dan $95 \%$ menggunakan internet untuk mengakses jejaring media sosial. (Fikawati Sandra, 2017). Sosial media merupakan salah satu yang populer saat ini, hal ini terlihat dari banyaknya kalangan pengguna sosial media, mulai dari kalangan pelajar, mahasiswa, pekerja, dan lain sebagainya. Temuan tersebut diperkuat dengan pendapat (Sugiharto, 2016) yang menyatakan bahwa profesi mahasiswa merupakan profesi yang paling banyak menggunakan internet daripada sektor lain.

Reynaldo \& Sokang (2017) dalam penelitian juga menyatakan bahwa bagi mahasiswa internet sudah menjadi prasyarat dalam pelaksanaan studinya. Hal ini dikarenakan mahasiswa dituntut untuk menggunakan internet dalam aktivitas kesehariannya khususnya untuk mengerjakan tugas kuliah. Kemudahan mendapatkan akses internet di kampus dimanfaatkan oleh mahasiswa untuk melakukan banyak aktivitas mulai dari mengerjakan tugas, searching, berkomunikasi bahkan bermain media sosial.

Tingginya akses penggunaan internet seperti dua sisi mata uang, 
disatu sisi memberikan banyak manfaat namun disisi yang lain menimbulkan permasalahan sosial yang baru. Permasalahan tersebut muncul pada individu yang menggunakan internet secara berlebihan seperti bermain game online diluar batas kewajaran hingga menyebabkan perubahan perilaku seperti bersikap kasar dan agresif, selain itu juga permasalahan intimidasi di dunia cyber yang biasa disebut cyberbullying (Kristiyono, 2017). Selain itu para pengguna internet dalam hal ini media sosial sangat mudah untuk mengekspresikan dan mempublikasikan emosi serta pikiran mereka termasuk pikiran dan emosi negatif untuk menyakiti orang lain (Ramdhani, 2016). Perilaku cyberbullying merupakan evolusi dari perilaku bullying tradisional yang selama ini kita kenal. Perbedaan kedua perilaku tersebut terletak pada media yang digunakan untuk melakukan bullying. Pada perilaku cyberbullying perilaku mengintimidasi dan mengganggu dilakukan melalui dunia cyber, internet atau media sosial.

Cyberbullying perlu mendapat perhatian intens dari banyak orang tua dan remaja dikarenakan dampak psikologis yang ditimbulkannya cukup berbahaya bagi kesehatan menyal anak. Banyak inividu yang tidak menyadari dan tidak peka terhadap terjadinya cyberbullying dikarenakan konten cyberbullying ini sering di sampaikan secara eksplisit melalui candaan dan olokolokan serta dianggap sebagai bahan candaan.

Pesatnya perkembangan teknologi komunikasi dan media massa menjadikan informasi sebagai komoditas utama dalam masyarakat modern. Begitu cepatnya informasi yang tersebar di masyarakat dan beragamnya informasi yang diterima oleh masyarakat mengakibatkan ledakan informasi (booming infomation). Lebih lanjut dengan maraknya penggunaan media sosial dikalangan remaja dan mahasiswa, saat ini Moral pengguna medsos (media sosial) Indonesia pun mulai dipertanyakan. Seperti berita yang ditulis (Pratama, 2016) yang menyebutkan bahwa :

"Bulan april 2016 yang lalu, seorang ayah meninggal akibat serangan jantung karena tak tahan menerima cacian pengguna internet (netizen) terhadap anaknya Sonya Depari. Kejadian tersebut ditengarai oleh video Sonya Depari yang menolak ditangkap polisi ketika merayakan kelulusan SMA dengan ricuh dan mencatut nama Deputi Penindakan Badan Narkotika Nasional (BNN), Arman Depari."

Melihat fenomena tersebut, bisa diketahui bahwa saat ini masyarakat kita masih menutup 
mata tentang pentingnya kecakapan bermedia, serta menerapkan sopan santun untuk membalas komentar publik. Dengan demikian saat ini perlu sebuah upaya untuk mengembangkan kemampuan literasi media, etika bermedia bagi pengguna medsos di Indonesia. Budi Sutedjo (dalam Novaldi, 2017). menjelaskan bahwa literasi media merupakan kemampuan individu dalam mengidentifikasi kebutuhan terhadap informasi. Lebih lanjut beliau mejelaskan bahwa persebaran berita hoax dan fake news bisa ditangkal dengan krmampuan literasi media. Dengan memiliki kemampuan literasi media maka individu tersebut memiliki kemampuan untuk mengkritisi dan menganalisis informasi yang ia terima (Evawani Elysa Lubis Rumyeni, 2013).

Menurut (Achmad, 2007) saat ini banyak informasi negatif yang diakses oleh remaja daripada informasi positif. Jika kemampuan literasi rendah maka individu tersebut akan mudah terprovokasi dan sebagai akibatnya ia akan membalas komentar publik dengan kata-kata kasar hingga pernyataan berbau SARA untuk menyerang subjek. Melihat fenomena tersebut perlu kiranya untuk meningkatkan pengetahuan dan kemampuan literasi sosial media, etika bermedia, dan dampak dari media kepada generasi muda Indonesia.
Salah satu faktor yang mementukan perilaku individu adalah kepribadian. Faktor genetik dan faktor lingkungan merupakan faktor yang secara khusus mempengaruhi terbentuknya kepribadian. Faktor genetik berperan untuk membentuk kepribadian yang unik dari individu sedangkan faktor lingkungan berperan membuat individu belajar berbagai pengalaman yang dialaminya. Kepribadian seseorang, pada umumnya bersifat menetap, mantap dan konsisten. Robbins dalam (dalam Mastuti, 2005). Untuk lebih memahami kepribadian beberapa ahli berusaha mengungkapkan beberpa pendekatan. Salah satu diantaranya adalah pendekatan teori The Big Five Personality. Teori ini mengelompokkan trait menjadi lima besar dengan dimensi bipolar. Adapun faktor-faktor di dalam big five meliputi Costa \& Mc Crae (dalam Mastuti, 2005): Neoroticism, Extraversion, Openness to Experience, Agreeableness dan Conscientiousness. Big Five Personality memiliki 30 trait kepribadian yang mendasari kepribadian individu. Dengan adanya pembahasan terhadap kecenderungan kepribadian yang lebih unik ini, diharapkan dapat menganalisis perilaku cyberbullying yang dilakukan oleh mahasiswa. 
Dari uraian diatas diperoleh informasi bahwa salah faktor yang mempengaruhi perilaku cyberbullying adalah faktor kepribadian dan kemampuan literasi. Berdasarkan uraian dan latar belakang permasalahan tersebut peneliti tertarik untuk melakukan penelitian dengan judul " Analisis Perilaku Cyberbullying di Tinjau dari Big Five Personality dan Kemampuan Literasi Sosial Media Mahasiswa Universitas PGRI Madiun”.

\section{METODE PENELITIAN}

Penelitian ini menggunakan metode penelitain deskriptif kuantitatif. Penelitian bertujuan untuk mengetahui gambaran perilaku cyberbullying di kalangan mahasiswa serta bagaimana hubungan dan pengarunya dengan kepribadian big five dan juga kemampuan literasi media yang dimiliki oleh mahasiswa. Populasi penelitian ini adalah mahasiswa Universitas PGRI Madiun, teknik samplling yang digunakan adalah stratified random sampling yaitu membagi populasi menjadi sub kelompok homogeny dan kemudian mengambil sample acak sederhana disetiap sub kelompok (Ghony \& Almanshur, 2009). Jumlah sample dalam penelitian ini sebanyak 350 mahasiswa. Analsis data yang akan digunakan untuk penelitian menggunakan analisis deskriptif kuantitatif.
Teknik pengumpulan data dalam penelitian ini menggunakan skala kecenderungan perilaku cyberbulling yang disusun oleh peneliti dengan mengacu pada aspek-aspek perilaku cyberbullying Willard (2005), yaitu : Flaming, Harassment, Denigration, Impersonation, Outing, Trickery, Exclusion, dan Cyberstalking. Sedangkan variabel kepribadian Big Five Personality menggunakan instrumen Big Five inventory 21 item yang telah diuji konfirmatori. Uji konfirmatori telah dilakukan oleh (Widyahastuti, 2016). Reliabilitas alat ukur ini adalah sebesar 0,83 . Sedangkan pada skala literasi media terdiri dari 3 aspek yaitu Teknik Skill, Critical Understanding, dan Communicative abilities. Reliabilitas alat ukur ini adalah sebesar 0,78

\section{HASIL DAN PEMBAHASAN}

Responden penelitian ini adalah mahasiswa Universitas PGRI Madiun yang masih aktif baik laki-laki ataupun perempuan. Peneliti menyebar instrumen sebanyak 400 namun tidak semuanya bisa dianalisis karena beberapa responden tidak menyelesaikan pengisian instrumen yang peneliti berikan. Dengan demikian Jumlah total responden dalam penelitian ini adalah 350 orang. Pada penelitian ini jumlah responden perempuan sebanyak 223 atau $63,7 \%$ dan responden lakilaki 127 atau 36,6\%. 
Berdasarkan hasil analisis data diketahui bahwa perilaku cyberbullying di Universitas PGRI Madiun berada pada kategori rendah. Hal ini terlihat dari prosentase skala cyberbullying yang menunjukkan kategori rendah sebesar 52,9 \% dan kategori sedang sebesar 41,7\%. Meskipun tidak ditemukan kategorisasi yang tinggi temuan mengenai $41,7 \quad \%$ mahasiswa yang termasuk dalam kategori sedang memiliki kecenderungan untuk melakukan perilaku cyberbullying.

Hasil penelitian ini sejalan dengan penelitian (Fatria, 2018) yang menunjukkan bahwa perilaku cyberbullying pada mahasiswa Universitas Pancasila cenderung rendah. Penelitian serupa yang ditemukan oleh (Gantina, Komalasari, Nabilah, \& Eka, 2012) yang menjelaskan bahwa perilaku cyberbullying bukan merupakan hal yang umum dilakukan oleh siswa di DKI Jakarta, karena lebih dari $83 \%$ - 96,2 \% siswa menyatakan bahwa mereka tidak pernah melakukan cyberbullying baik melalui emai, chat room, instant messaging maupun website. Penelitian yang dilakukan oleh (Sagita, Mamesah, \& Filliani, 2012) menjelaskan bahwa siswa kelas X jasa Boga SMK Negeri 30 Jakarta secara umum berada pada kategori sedang yaitu kategori tinggi $11,5 \%$, sebanyak $80,8 \%$, dan rendah sebanyak $7,7 \%$
Berdasarkan kategorisasi bentuk perilaku cyberbullying dapat diperoleh informasi kecenderungan perilaku cyberbullying yang sering dilakukan mahasiswa, antara lain trickery (tipu daya) atau membujuk orang dengan tipu daya untuk mendapatkan rahasia atau foto pribadi orang tersebut sebesar $73,1 \%$, perilaku secara sengaja mengeluarkan seseorang dari group online atau yang biasa disebut perilaku Exclusion (pengeluaran) sebesar 64,3 \%, perilaku menyebarkan rahasia orang lain atau foto-foto pribadi orang lain yang biasa disebut Outing sebesar $60,8 \%$, perilaku cyberstalking sebesar 52,9 \% dan pencemaran nama baik (denigration) sebesar $50 \%$. Hal ini serupa dengan hasil penelitian (Satalina, 2014) menyebutkan bahwa bentuk perilaku cyberbullying yang banyak dilakukan adalah Outing sebesar $18,8 \%$ dan trickery sebesar $18,8 \%$.

Hasil penelitian deskriptif kepribadian big five mahasiswa Universitas PGRI Madiun menunjukkan bahwa rata-rata mahasiswa memiliki big five personality yang tinggi yaitu sebesar $77,4 \%$ dan sedang $22,6 \%$. Jika dilihat berdasarkan sifat/trait yang membentuk big five personality maka mahasiswa yang memiliki sifat Openess tinggi sebesar $\quad 74,6 \%$, sifat Conscientiouness tinggi sebesar 62,3\%, sifat Agreeableness tinggi 
sebesar 56,3, sifat Extraversion tinggi sebesar 78,9, sifat Neoriticism rendah sebesar 64,5.

Sedangkan kemampuan literasi media mahasiswa Unipma rata-rata berada pada kategori tinggi sebesar $92,8 \%$ sisanya berada pada kategori sedang. Teknik skill berada pada kategori tinggi $77,4 \%, \quad$ Critical understanding $86,3 \%$ dan Communicative abilities $84,9 \%$. Hal ini sesuai dengan penelitian Wijaya, Sudjimat, \& Nyoto, (2016) tentang kemampuan yang dibutuhkan pada abad ke 21 khusunya terkait dengan ketrampilan teknologi dan media informasi.

Berdasarkan uji korelasi antar skor variabel perilaku cyberbullying dan big five personality diperoleh $\mathrm{r}=-0,277 \mathrm{r}$ tanda negatif menggambarkan hubungan yang berlawanan artinya semakin tinggi big five personality maka semakin rendah perilaku cyberbullying. Probabilitas perilaku cyberbullying dan big five personality adalah $0,00<0,05$ yang berarti ada hubungan atau korelasi yang signifikan. Sedangkan korelasi antara perilaku cyberbullying dan literasi media diperoleh $r=-0,106 r$ tanda negatif menggambarkan hubungan yang berlawanan artinya semakin tinggi literasi media maka semakin rendah perilaku cyberbullying. Probabilitas perilaku cyberbullying dan big five personality adalah 0,47 $>0,05$ yang berarti tidak ada hubungan atau korelasi yang signifikan. Namun antara big five personality dan literasi media menunjukan adanya korelasi hal ini dapat dilihat dari nilai sig $0,00<$ dari 0.05. yang artinya semakin tinggi big five personality semakin tinggi pula kemampuan literasinya. Untuk lebih jelasnya bisa dilihat pada tabel.

Hasil analisis antara big five personality dan adalah literasi media terhadap perilaku cyberbullying menunjukkan nilai $\mathrm{R}$ sebesar 0,282. hal ini menunjukkan bahwa ada korelasi antara variabel big five personality (X1) dan (X2) literasi media terhadap cyberbullying. Namun korelasinya lemah. Adapun sedangkan kontribusi/sumbangan efektifnya sebesar $7,9 \%$ sedangkan sisanya $95,8 \%$ ditentukan oleh faktor yang lain.

Berdasarkan penelitian yang dilakukan diperoleh informasi tambahan yaitu rentangan usia responden adalah usia 18 tahun hingga 23 tahun. Subjek penelitian rata-rata berada pada usia 22 tahun sebesar 35,4\% dan usia 20 tahun sebesar 25,4 \%. Mahasiwa di Universitas PGRI Madiun melakukan kegiatan bersosial media menggunakan Smart phone yaitu sebesar 97,14. Akun media sosial yang banyak digunakan oleh mahasiswa Universitas PGRI 
Madiun adalah instagram sebesar $68,8 \%$ dan whatsapp $90 \%$. Sedangkan aktivitas sosial media yang sering dilakukan oleh mahasiswa adalah chating $91,7 \%$, mengunggah foto dan mengupload status di mesia sosial.

\section{SIMPULAN}

Penelitian yang dilakukan peneliti Tujuan dari penelitian ini adalah untuk memperoleh gambaran tentang kecenderungan perilaku cyberbullying di Universitas PGRI Madiun. Berdasarkan temuan dari peneliti menunjukkan bahwa perilaku cyberbullying memang bukan merupakan hal yang umum dilakukan oleh mahasiswa Universitas PGRI Madiun karena $52,8 \%$ termasuk kedalam kategori yang sedang dan sisanya 47,14\% masuk ke dalam kategori sedang. Sebagai informasi tambahan bahwa penelitian ini dilakukan kepada mahasiswa dengan rentang usia usia 18 tahun hingga 23 tahun. Subjek penelitian rata-rata berada pada usia 22 tahun sebesar $35,4 \%$ dan usia 20 tahun sebesar $25,4 \%$. Mahasiwa di Universitas PGRI Madiun melakukan kegiatan bersosial media menggunakan Smart phone yaitu sebesar 97,14. Akun media sosial yang banyak digunakan oleh mahasiswa Universitas PGRI Madiun adalah instagram sebesar 68,8 dan whatsapp $90 \%$. Sedangkan aktivitas sosial media yang sering dilakukan oleh mahasiswa adalah chating $91,7 \%$, mengunggah foto dan mengupload status di mesia sosial.

Hasil penelitian (Adiarsi, Stellarosa, \& Silaban, 2017) menyebutkan bahwa facebook menjadi media sosial favorit di Indonesia meskipun kini produk digital sejenis makin menjamur. Sedangkan hasil penelitian pada mahasiwa UNIPMA media sosial favirit saat ini adalah instagram dan whatsapp.

\section{DAFTAR PUSTAKA}

Achmad. (2007). Literasi informasi : ketrampilan penting di era global*). Access, 1(April 2007), 1-8.

Adiarsi, G. R., Stellarosa, Y., \& Silaban, M. W. (2017). Literasi Media Internet di Kalangan Mahasiswa. Humaniora, 6(4), 470.

https://doi.org/10.21512/humani ora.v6i4.3376

Dewi, N., \& Trikusumaadi, S. K. (2017). Bahaya Kecanduan Internet dan Kecemasan Komunikasi terhadap Karakter Kerja Sama pada Mahasiswa. Jurnal Psikologi, 43(3), 220. https://doi.org/10.22146/jpsi.168 29

Evawani Elysa Lubis Rumyeni, . (2013). Analisis Tingkat Literasi Media Mahasiswa Di Jurusan Ilmu Komunikasi. Politik, Birokrasi Dan Perubahan Sosial Dalam Upaya Membangun 
Karakter Bangsa, (November), 1-19. Retrieved from https://repository.unri.ac.id/xml ui/bitstream/handle/123456789/ 7358/Artikel Literasi Media\%2C Evawani EL.pdf?sequence $=1 \&$ isAllowed $=\mathrm{y}$

Fatria, R. Q. (2018). Prosiding Konferensi Nasional Peneliti Muda Psikologi Indonesia 2018. Gambaran Perilaku Cyberbullying Mahasiswa Universitas Pancasila, 3 No 1(1), 13-18.

Fikawati Sandra, S. A. dan V. A. (2017). Cegah Stunting itu Penting. 1-27.

Gantina, Komalasari; Nabilah; \& Eka, W. (2012). STUDI PERILAKU

CYBERBULLYING SISWA SMAN DI DKI JAKARTA. Jurnal Inshight, 1 No 1, 3-12. Retrieved from http://journal.unj.ac.id/unj/inde x.php/insight/article/view/1166

Ghony, M.d \& Almanshur, F. 2012. Metodologi Penelitian Kualitatif. Yogyakarta: Arruzz Media.

Kristiyono, J. (2017). Budaya Internet: Perkembangan Teknologi Informasi Dan Komunikasi Dalam Mendukung Penggunaan Media Di Masyarakat. Scriptura, 5(1), 23-30. https://doi.org/10.9744/scriptur a.5.1.23-30

Mastuti, E. (2005). Analisis Faktor Alat Ukur Kepribadian Big Five (Adaptasi dari IPIP) pada Mahasiswa Suku Jawa. Insan,
7(3), 264-276.

Novaldi. (2017). Pakar IT: Tangkal Hoax dengan Literasi Media. Kominfo. Retrieved from https://kominfo.go.id/content/de tail/9725/pakar-it-tangkal-hoaxdengan-literasimedia/0/sorotan_media

Pratama, R. A. (2016). Awas Cyberbullying Sebabkan Kematian! Retrieved from http://isolapos.com/2016/06/awa s-cyberbullying-sebabkankematian/

Ramdhani, N. (2016). Emosi Moral dan Empati pada Pelaku Perundungan-siber. Jurnal Psikologi, $\quad 43(1), \quad 66$. https://doi.org/10.22146/jpsi.129 55

Reynaldo, R., \& Sokang, Y. A. (2017). Mahasiswa dan Internet: Dua Sisi Mata Uang? Problematic Internet Use pada Mahasiswa. Jurnal Psikologi, 43(2), 107. https://doi.org/10.22146/jpsi.172 76

Sagita, D. R., Mamesah, M., \& Filliani, R. (2012). GAMBARAN PERILAKU CYBERBULLYING SISWA DI SMK NEGERI 30 JAKARTA. Jurnal Bimbingan Dan Konseling Insight, Vol 1 No 2, 83-88. Retrieved from http://journal.unj.ac.id/unj/index .php/insight/article/view/1492

Satalina, D. (2014). Kecenderungan Perilaku Cyberbullying Ditinjau Dari Tipe Kepribadian Ekstrovert Dan Introvert. Jurnal Ilmiah Psikologi Terapan, 2 No 2 Jan, 294-310. Retrieved from 
https://www.bps.go.id/dynamict able/2018/05/18/1337/persentas e-panjang-jalan-tol-yangberoperasi-menurutoperatornya-2014.html

Sugiharto, B. A. (2016). Pengguna Internet di Indonesia Didominasi Anak Muda.

Widyahastuti, R. (2016). Pengaruh Kepribadian (Big Five Personality) Terhadap Multitasking. Fakultas Psikologi Universitas Muhammadiyah Malang skripsi tidak diterbitkan.

Wijaya, E. Y., Sudjimat, D. A., \& Nyoto, A. (2016). Transformasi Pendidikan Abad 21 Sebagai Tuntutan. Jurnal Pendidikan, 1, 263-278. Retrieved from http://repository.unikama.ac.id/ 840/32/263-278 Transformasi Pendidikan Abad 21 Sebagai Tuntutan Pengembangan Sumber Daya Manusia Di Era Global.pdf. diakses pada; hari/tgl; sabtu, 3 November 2018. jam; 00:26, wib.

Willard, N. (2005). Cyberbullying and cyberthreats. Washington: U.S. Department of Education. 